Mini Review

\title{
NON-HORMONAL FEED ADDITIVES AS AN ALTERNATIVE IN ANIMAL REPRODUCTION
}

\author{
D. Mihaylova ${ }^{1}$, A. Krastanov ${ }^{1}$, N. Vasilev $^{2}$ \\ ${ }^{1}$ Department of Biotechnology, University of Food Technologies, Plovdiv, Bulgaria \\ ${ }^{2}$ Department of Obstetrics, Reproduction and Reproductive Disorders, Trakia University, \\ Stara Zagora, Bulgaria
}

\begin{abstract}
Nowadays, a modern trend of the animal husbandry is to increase the reproductive potential of livestock and poultry. There is a large interest worldwide in discovering new and safe non-hormonal biologically active substances obtained from natural sources, which could substitute the synthetic hormones. The positive influence on reproduction in livestock of the biologically active substances of natural origin such as isoflavones, carotenoids, minerals, phytohormones, PUFAs, etc. represent a potential alternative. These substances are derived from various plant sources and micro and macro algae as well. In addition, those substances could provoke positive changes in animal reproduction practices, corresponding to the modern EU requirements for quality and safe for the human health nutrients. The present mini-review summarizes the known in respect of the trend of substitution of the hormonal ones and outlines the potential non-hormonal additives in livestock husbandry.
\end{abstract}

Key words: livestock, non-hormonal biologically active substances, reproduction.

\section{INTRODUCTION}

Satisfying increasing and rapidly changing demands for food products of animal origin, while at the same time sustaining the natural resource base (soil, water, air, and biodiversity), is one of the major challenges facing world agriculture today. A growing global population, combined with factors such as changing socio-demographics, will reinforce the world's resources to provide not only more but also different types of food.

According to UN data, the global population growth is foreseen to be of $50 \%$ since 2000 to almost 10 billion by 2050 (1). However, it is generally accepted that animal-based foods produce higher levels of greenhouse gases (GHG) than plant-based foods and these are associated with climate change (2) - a problem of a significant matter for modern society.

There has been an increasing pressure on the livestock sector to meet the growing demand

*Correspondence to: Nasko Vasilev, Trakia University, Department of Obstetrics, Reproduction and Reproductive Disorders, 6000 Stara Zagora, Bulgaria,nasvas@abv.bg for high-value animal protein. The world's livestock sector is growing at an unprecedented rate and the driving force behind this enormous surge is a combination of population growth, rising incomes and urbanization. Annual meat production is projected to increase from 258 million tonnes in 2005-2007 to 374 million tonnes by 2030 (3).

Livestock production is the world's largest user of land, either directly through grazing or indirectly through the consumption of fodder and feed grains. Globally, livestock production currently accounts for some 40 percent of the gross value of agricultural production. In industrial countries, this share is more than half. In developing countries, where it accounts for one-third, its share is rising quickly; livestock production is increasing rapidly as a result of growth in population and incomes and changes in lifestyles and dietary habits. Livestock products provide one-third of humanity's protein intake, and are a contributing cause of obesity and a potential remedy for undernourishment (4).

Growth in the livestock sector has consistently exceeded that of the crop sector. The total 
demand for animal products in developing countries is expected to more than double by 2030 (5).

Meeting these challenges raises crucial global and national public policy issues that must be addressed. In this point of view the animal breeding, feeding and reproduction are of crucial interest. In the present review paper, we demonstrated that non-hormonal feed additives are a potent alternative influencing animal reproductivity.

\section{Reproduction}

In order to achieve sustainability in any livestock production system - milk, meat, draft, and replacement animals an efficient reproductive performance and monitoring are imperative. In this regard, one of the most important tasks of modern animal husbandry is to increase the reproductive potential of livestock (6). Indeed the reproductive success in livestock is assumed as essential for the economic benefits of producers and affects the cost of the animal products. In many livestock production systems, poor fertility is a major factor that limits productivity. The reproductive performance is under continuously investigation (7). Numerous of the research data increases our knowledge of the fundamental biology of reproduction, which reinforces the development of state-ofthe-art management strategies that optimize reproductive efficiency and minimize economic loss.

It has to be noted, that inefficient reproduction in livestock may be caused by various factors including: abnormal or absent reproductive cycles; failure to show estrus (heat); embryonic and fetal loss and mortality during the neonatal period; failure to reach puberty at an optimum age or an inability of young females to conceive early in the breeding season; environmental stressors such as temperature extremes or changes in photoperiod (day and night cycle), or production of sperm with a low potential for fertilization (8).

In order to improve reproduction conventional techniques are widely used in addition to modern reproductive technologies, which broad the reproductive performance in various domestic species of livestock. Scientists applied the modern biotechnologies in studying and manipulating the reproductive process both in vitro and in vivo.
MIHAYLOVA D., et al. The induction and synchronization of heat in the case of small ruminants is often done with treatments based on exogenous hormones. Progesterone, or equivalent substances, is the most commonly used hormones for the estrus synchronization of cattle $(9,10)$. Hormonal interventions have been used to increase the probability of estrous detection and insemination, and to increase pregnancy rates of dairy cattle under a variety of management systems (11). Fries et al. (2010) reported successful induction and synchronization of ovulation in sows using a gonadotropinreleasing hormone analog with reduced estrus length and the interval between estrus onset and ovulation. In brief, the hormones used to control the estrous cycle mimic the reproductive hormones (11).

Heat stress affects the fertility and reproductive livestock performance by compromising the physiology reproductive tract, through hormonal imbalance, decreased oocyte quality and poor semen quality, and decreased embryo development and survival.

The effects of heat stress on livestock can be minimized via adapting suitable scientific strategies comprising physical modifications of the environment, nutritional management and genetic development of breeds that are less sensitive to heat stress (13).

In addition, a global trend is to improve livestock production and reproduction of breeds adapted to the local environments, with emphasis on the characterization of livestock genetic resources, the identification of genes controlling productive and economic traits, and the establishment or the strengthening of artificial insemination programs. Last but not least the application of animal manure to agricultural land has been identified as one of the main source of estrogens in the environment (14) determining nutrition and animal production as crucial.

Given the serious threat posed by estrogens as pollutants, Kistanova (2003) summarized various possibilities of natural derived products to improve the male and female reproductive functions. Among them placenta, colostrum, plant extracts and plant hormones are reported as bio stimulants of plant and animal origin.

Taking into account the growing demand for food free from pharmacological residues the 
MIHAYLOVA D., et al.

requirements for sustainable reproductive practices and against synthetic hormones as progestogens used to synchronize heat are well justified (11). Possible human friendly approach for increasing livestock productivity could be based on innovative and efficient animal nutrition.

\section{Animal nutrition}

Nutrition could be a serious limitation to livestock production especially when feed resources are inadequate in both quality and quantity (16). However, animal health and welfare have always been a priority in their nutrition. Feed is the most important input in all livestock production systems in terms of cost, and the availability of low priced, highquality feeds is critical if livestock production is to remain competitive and continue to grow to meet the demand for animal protein. Last but not least consuming animal products, people are affected as well by the feed.

Based on this the high-quality nutrition is considered as one of the main factors for improving the reproductive potential of livestock and poultry (17). As confirmation, several research papers are focused on nutrition's direct influence on folliculogenesis in females and spermogenesis in male livestock and poultry $(18,19)$.

Feeding forages containing high-quality proteins and fats, as well as biologically active components (vitamins, micro- and macroelements, carotenoids and other pigments, polyphenols, furostanol saponins) in amounts required for the respective species of breeding livestock and poultry allows stimulation of sexual functions (20).

It was recognized that the deficient and excess nutrient supply could be equally detrimental. Even nutritional treatments that result in highly desirable responses for one reproductive state may become counterproductive in a subsequent phase or for the reproductive economy of the animal as a whole $(21,22)$.

Synthetic hormones and bioactive substances (vitamins, pigments and isoflavones) which have been used in the feed industry are considered to cause numerous side effects as carcinogenesis, liver and kidney damage, allergies in consumers because of accumulation in milk, meat, and eggs (23).
Furthermore, several researchers reported the synthetically produced substances (hormones, vitamins, pigments and other biologically active substances) to possess significant lower effect than those obtained from natural sources $(24,25)$. The above mentioned and the new eco-friendly approach determine the increasing interest in discovering new and safe BAS obtained from natural sources as justifiable. Such substances could serve as substitution of the synthetic hormones (26).

\section{Non-hormonal additives to the feed}

Feed additives represent various classes of molecules, compounds, or organisms that promote ingestion, absorption, assimilation of nutrients, growth, and health. They affect physiological processes, such as immune function, stress resistance, and reproduction. Feed additives include feeding attractants, immune stimulants, prebiotics, probiotics, acidifiers, essential oils, or other inclusions. These additives are usually not required nutrients (27).

While the use of hormonally active substances in animal production rose, opposition to their use also increased, because of the theoretical possibility that residues in edible tissues might endanger consumers (28). However, Synthetic hormones and biologically active substances (BAS), still used in the animal husbandry practice in many countries for stimulating the reproductive parameters, accumulate in the milk, meat and eggs (23).

There is a large interest worldwide in discovering new and safe BAS obtained from natural sources, which will substitute the synthetic hormones. BAS influences the genic expression, either via signal ways or directly. They have the ability to regulate the growth factors and enzymes, as well as the molecules related to the apoptosis changes within the cells. BAS are assimilated in full and have a positive impact on various physiological processes including a pronounced antioxidant activity, strengthen the immune system, improve the functions of particular organs and systems, among them the reproductive system, etc. (23).

Among many dietary factors natural antioxidants have special importance in the maintenance of high growth levels, reproduction and immuno-competence in poultry production. 
The anti-oxidant/pro-oxidant balance can be modulated by sub-optimal diets and poor nutrient intakes, or positively affected by dietary supplementation. Therefore, feed components can change this balance and may influence such effects as the rate of ageing and disease resistance in humans and animals. Animal feeds contain a range of different compounds that possess antioxidant activities including vitamin $\mathrm{E}$, consisting of 8 compounds (4 tocopherols and 4 tocotrienols), carotenoids (more than 600 compounds), flavonoids (more than 8,000 compounds), ascorbic acid, and some other compounds (17).

Vitamins and minerals are reported to affect reproductive function since they play cellular roles in metabolism, maintenance, and growth in addition to specific roles and requirements in reproductive tissues. Vitamin A status is of particular concern in maintaining optimal reproductive efficiency in cattle, but vitamins $\mathrm{D}, \mathrm{E}$, and $\mathrm{C}$ also may be important. Under some circumstances, even the availability of $\mathrm{B}$ vitamins may influence reproductive performance. Deficiencies of a number of minerals, including $\mathrm{Ca}, \mathrm{P}, \mathrm{Se}, \mathrm{Zn}, 1, \mathrm{Cu}$, Mo, $\mathrm{Co}$, and $\mathrm{Mn}$, can affect reproduction (22).

Lycopene as a natural carotenoid, and a powerful antioxidant found in tomatoes, watermelons, papayas, and pink grapefruits (29) was reported in in vivo as well as in vitro reports to improve sperm motility, viability, morphology, and testicular oxidative balance following exposure to medication $(30,31)$, organic pollutants (32), oxidative stress promoters $(33,34)$ or mycotoxins $(35)$.

Plant secondary metabolites such as terpenes, phenolic compounds and alkaloids in some cases can be toxic to animal's metabolism, affecting the nervous system, immune, endocrine and reproductive $(36,37,38)$. These compounds are also a significant source of anti-inflammatory and antioxidants, playing an important role as inhibitors of enzymes (39).

Supplementation of L-ascorbic acid, both singly and in combination with 1-tocopherol acetate, was found to be helpful to heatstressed layers (40). The addition of common macro minerals $\mathrm{Na}^{+}$and $\mathrm{K}^{+}$in feed increases dry matter intake and production performance (41). Inclusion of ascorbic acid in the feed ameliorates, heat stress induced problems like poor immunity, feed intake, weight gain, oxidative stress, body temperature, fertility and semen quality (40).

The use of even a very small amount of biomass of micro-aquatic plants strengthens the immune system of animals, thereby stimulating their growth and improving their reproductive properties (42). Positive effects were reported when supplementing the feed of swine, sheep, cattle and rabbits (43-46).

Reproductive processes in animals offer numerous advantages and scope for the use of novel biotechniques. Nevertheless, these emerging techniques should be judicially supplemented with good practices in animal health, nutrition and management at the level of stakeholders for manipulation and improvement of health, production and reproductive performance of any livestock species, which will facilitate the production and dissemination of superior germplasm thereby enhancing the overall productivity of livestock species (47).

\section{CONCLUSIONS}

Taking into account the great interest toward non-hormonal additives in animal husbandry, summarizing the known is important in respect to the trend of substitution of the hormonal ones. The numerous advantages of natural product supplementation could be a potential approach for successful and effective animal reproductivety and to be harmless both for animals and humans.

\section{ACKNOWLEDGMENT}

This work was supported by the National Scientific Program "Reproductive Biotechnology in Animal Breeding in Bulgaria (NNP REPROBIOTECH)" № 0406-105 of the Ministry of Education and Science of the Republic of Bulgaria.

\section{REFERENCES}

1. World Population Prospects 2019: Highlights June 2019. https://population.un.org/wpp. UNPopulation.

2. Tilman, D. and Clark, M., Global diets link environmental sustainability and human health. Nature, 515:518-522, 2014.

3. Alexandratos, N. and Bruinsma, J., World Agriculture Towards 2030/2050: The 2012 Revision (Food and Agriculture Organization of The United Nations, Rome, 2012. 
4. FAO, Livestock's long shadow. Environmental issues and options. ISBN 978-92-5-105571-7, 2006.

5. Bruinsma, J., World Agriculture: Towards 2015/2030: An FAO Study PERSPECTIVE edited by Jelle http://www.fao.org/3/ay4252e.pdf, 2003.

6. Abadjieva, D. and Kistanova, E. Opportunities to stimulate reproductive function in female animals. Niva Povoljaq. Zootech. 4 (21), 71-75, 2011.

7. Lean, I., Matthew, J., Lucy, C., McNamara, John P., Barry, J. Bradford, Elliot Block, Thomson, J. M., Morton, J. M., Celi, P., Rabiee, A. R., Santos, J.E.P., Thatcher, W. W., LeBlanc, S. J., Invited review: Recommendations for reporting intervention studies on reproductive performance in dairy cattle: Improving design, analysis, and interpretation of research on reproduction, Journal of Dairy Science, Volume 99, Issue 1, 1-17, ISSN 0022-0302, 2016.

8. USDA, United States Department of Agriculture. National Institute of Food and Agriculture. Animal Reproduction. https://nifa.usda.gov/program/animalreproduction http://wwwnaweb.iaea.org/nafa/aph/topic-animalbreeding.html

9. Bradecamp, E. A., CHAPTER 3 - Estrous Synchronization, Editor(s): Juan C. Samper, Jonathan F. Pycock, Angus O. McKinnon, Current Therapy in Equine Reproduction, W.B. Saunders, Pages 22-25, ISBN 9780721602523, 2007.

10.Islam, R., Veterinary World, Synchronization of Estrus in Cattle: A Review. Vol.4(3):136-141, 2011.

11.Lucy, M.C, McDougall, S., Nation, D. P., The use of hormonal treatments to improve the reproductive performance of lactating dairy cows in feedlot or pasture-based management systems, Animal Reproduction Science, Volumes 82-83, Pages 495-512, ISSN 0378-4320, 2004.

12.Fries, H.C.C., Souza, L. P., Faccin, J.E.G., Reckziegel, M. V., Hernig, L., Marimon, B. T., Bernardi, M. L., Wentz, I., Bortolozzo, F. P., 3. Induction and synchronization of ovulation in sows using a Gonadotropinreleasing Hormone Analog (Lecirelin). Anim. Reprod, v.7, n.4, p.362-366, Oct./Dec., 2010.

13.Collier, R. J., Dahl, G. E., VanBaale, M. J., Major advances associated with environmental effects on dairy cattle.
MIHAYLOVA D., et al.

Journal of Dairy Science, 89:1244-125, 2006.

14.Arnon, S., O. Dahan, S., Elhanany, K., Cohen, I., Pankratov, A., Gross, Z., Ronen, S., Baram, L., Shore, S., Transport of testosterone and estrogen from dairy-farm waste lagoons to groundwater Environ. Sci. Technol., 42, 5521-5526, 2008.

15.Kistanova, E., The use of the biologically active substances from plant and animal products for the stimulation of the reproduction in domestic animals. Biotechnology in animal husbandry. 19(12), 1-92, 2003.

16.Tona, O., Current and Future Improvements in Livestock Nutrition and Feed Resources By Grace Submitted: July 19th 2017Reviewed: December 13th 2017 Published: July 18th 2018.

17.Surai, P.F., Natural antioxidants in poultry nutrition: New developments. Pp. 669-676 in Proc. 16th European Symp. Poult. Nutr. Strasbourg, France, 2007.

18. Yassein, A., Niveen, D.M., and Ezzo, O.H., Some productive, reproductive and physiological Effects of using different dietary protein levels in Rabbit does. Iranian J. Appl. Anim. Sci. 1, 183-192, 2011.

19.Cordier, A.G., Leveille, P., Dupont C., Dietary lipid and cholesterol induce ovarian dysfunction and abnormal LH response to stimulation in rabbits. Plos One. 8(5), 63101, 2013.

20.Surai, P.F., Natural antioxidants in avian nutrition and reproduction. Nottingham University Press, Nottingam, United Kingdom, 2002.

21.Robinson, J. J., Nutrition in the reproduction of farm animals. Nutrition Research Review, 3: 253-276, 1990.

22.Hurley, W. L., Doane, R. M., Recent developments in the roles of vitamins and minerals in reproduction. Journal of Dairy Science, 72: 784-804, 1989.

23. Grigorova, S., Abadjieva, D., Gjorgovska, $\mathrm{N}$., Influence of natural sources of biologically active substances on livestock and poultry reproduction. Iran. J. Appl. Anim. Sci., 7, 189-195, 2017.

24.Topliss, J. G., Clark, A. M., Ernst, E., Hufford, C. D., Johnston, G.A.R., Rimoldi, J. M., Weimann, B. J., Natural and synthetic substances related to human health. Pure. Appl. Chem. 74, 1957-1985, 2002. 
25.Munir, N., Sharif, N., Naz, S., Manzoor, F., Algae: A potent antioxidant source. Sky J. Microbiol. Res. 1, 22-31, 2013.

26.Grigorova, S., Sources and importance of natural antioxidants in animal nutrition. Zivotnovudni Nauki. 51, 46-52, 2014.

27.Watts, S. A., Addison, L., Lawrence, J., Lawrence, M., Chapter 10 - Nutrition, Editor(s): John M. Lawrence, Developments in Aquaculture and Fisheries Science, Elsevier, Volume 38, 155-169, ISSN 0167-9309, ISBN 9780123964915, 2013.

28.Velle, W., The Use Of Hormones in Animal Production. Veterinary College of Norway, Department of Physiology. Oslo: FAO Corporate Document Repository, 2017.

29.Atasoy, N., Biochemistry of lycopene. Journal of Animal and Veterinary Advances 11, 2605-2610, 2012.

30.Atessahin, A., Karahan, I., Turk, G., Gur, S., YIlmaz, S., Ceribas, A. O., Protective role of lycopene on cisplatin induced changes in sperm characteristics, testicular damage and oxidative stress in rats. Reprod Toxicol, 21:42-47, 2006a.

31.Atessahin, A., Turk, G., Karahan, I., Yilmaz, S., Ceribasi, A. O., Bulmus, O., Lycopene prevents adriamycin-induced testicular toxicity in rats. Fertil Steril., 85:1216-1222, 2006b.

32.Tamiselvan, P., Bharathiraja, K., Vijayaprakash, S., Balasubramanian, M. P., Protective role of lycopene on bisphenol A induced changes in sperm characteristics testicular damage and oxidative stress. International Journal of Pharma and Bio Sciences, 4, 131-143q 2013.

33.Zini, A., San Gabriel, M., Libman, J., Lycopene supplementation in vitro can protect human sperm deoxyribonucleic acid from oxidative damage. Fertility and Sterility, 94, 1033-1036, 2010.

34.Tvrdá, E., Kováčik, A., Tušimová, E., Paál, D., Mackovich, A., Alimov, J., Lukáč, N., Antioxidant efficiency of lycopene on oxidative stress - induced damage in bovine spermatozoa. $J$ Anim Science and Biotechnology. 7, 1, 50, 2016.

35.Tas, M., Saruhan, B. G., Kurt, D., Yokus, B., Denli, M., Protective role of lycopene on aflatoxin B1 induced changes in sperm characteristics and testicular damages in rats. Kafkas Universitesi Veteriner Fakultesi Dergisi 16, 597-604, 2010.
MIHAYLOVA D., et al.

36.D'Mello, J.P.F., Devendra, C., Leguminous leaf meals in non-ruminant nutrition, In: Tropical Legumes in Animal Nutrition, J.P.F. D'Mello and C. Devendra (Eds.), CAB International, Wallingford, UK, 1995.

37.Furlan, S., Panter, K.E., Pfister J.A., Stegelmeier, B.L., Fetotoxic effects of locoweed (Astragalus lentiginosus) in pregnant goats, In: International Symposium on Poisonous Plants, Logan, Poison Plants Res Lab., 130-35, 2007.

38.Stegelmeier, B.L., Lee, S.T., James, L.F., Gardner, D.R., Panter, K.E., Ralphsp M.H., Pfister, J.A., The comparative pathology of locoweed poisoning in livestock, wildlife and rodents, In: International Symposium on Poisonous Plants, Logan: Poison Plants Res Lab., 359-65. CAB International, Walliingford, U.K., 2007.

39.Falé, P.L.V., Madeira, P.J.A., Florêncio, M.H., Ascensão, L., Serralheiro, M.L.M., Function of Plectranthus barbatus tea as neuronal acetylcholinesterase inhibitor, Food and Function, 2, 130-136, 2011.

40.Abdin, Z., Khatoon, A., Heat stress in poultry and the beneficial effects of ascorbic acid (vitamin C) supplementation during periods of heat stress. World's Poultry Science Journal, 69:135-152, 2013.

41.Chauhan, S.S., Celi, P., Leury, B., Liu, F., Dunshea, F.R., Exhaled breath condensate hydrogen peroxide concentration, a novel biomarker for assessment of oxidative stress in sheep during heat stress. Animal Production science, 56(7):1105-1112, 2015.

42.Abadjieva, D., Schumkov, K., Kistanova, E., Kacheva, D., Georgiev, B, Opportunities for the improvement of the reproductive performances in female animals. Biotechnol. Anim Husb, 27, 365372, 2011.

43.Shimkus. A., Martinavicius, V., Kulpus, J., Simkenee, A., Knietkute, N., Stankeviciene, M., The effect of microalgae Spirulina platensis on physiological processes and productivity of fattening pigs. Zivotnovudni Nauki, 45, 36-40, 2008a.

44.Shimkus, A., Oberanskas, V., Zelvyte, R., Monkeviciene, I., Laugalis, J., Simkiene, A., Juozaitiene, V., Juozatis, A., Bartkeviciute, Z., The effect of microalga Spirulina platensis on milk production and some microbiological and biochemical parameters in dairy cows. Zivotnovudni Nauki. 45, 42-49, 2008b. 
45.Holman B.W.B., Malau-Aduli A.E.O., Spirulina as a livestock supplement and animal feed. J. Anim. Physiol. Anim. Nutr, 97, 615-623, 2013.

46.Abadjieva, D., Estimation of the Spirulina platensis and Vemoherb-T supplementation effect on the reproductive parameters of
MIHAYLOVA D., et al. female rabbits. $\mathrm{Ph}$ D. Thesis. Sofia Univ., Sofia, Bulgaria, 2015.

47.Choudhary, K. K., Kavya, K. M., Jerome, A.and Sharma, R. K. Advances in reproductive biotechnologies. Vet Word, Apr; 9(4): 388-395, 2016. 